http://https://ejournal.iai-tribakti.ac.id/index.php/perbankan

\title{
Analisis Strategi Pemasaran Dalam Menghadapi Persaingan Pasar Pada Toko Roti Merah Delima Kediri
}

\section{Marketing Strategy Analysis in Facing Market Competition At the Merah Delima Bakery Kediri}

\author{
Khoiru Rohmah', Ahmad Badi' ${ }^{2}$ \\ ${ }^{1}$ Prodi Perbankan Syariah IAIT Kediri, ${ }^{2}$ Institut Agama Islam Tribakti Kediri \\ ${ }^{1}$ khoirurohmah8@gmail.com, ${ }^{2}$ badifauzan00@gmail.com,
}

\begin{abstract}
Marketing strategy is a comprehensive and orderly plan of every design that has been made by companies and entrepreneurs that include a series of activities that must be carried out for marketing. Competition is a competition from various other competitors in order to gain an advantage in the market. There are also two kinds of competition, healthy and unfair competition. In the market world, competition must be accompanied by strong efforts to produce the desired target. From the description above, formulate the problem of this research, how the marketing strategy is applied, the marketing strategy in facing market competition. This study uses a qualitative descriptive approach to describe summarizing various conditions. Data collected using the method of observation, interviews (interviews), and documentation. This final stage uses data validity with credibility, transferability, dependability, confirmability. The results of this study, the marketing strategy used at the Merah Delima Kediri Bakery uses a marketing mix including: Products that have various variants both sweet, salty, and tasteless. Selling prices from Rp. 3000 upwards. The promotions used are traditional and modern. Distribution (place) is in an area that is easy to reach and has branches in other areas. From the marketing strategy in facing market competition, namely using SWOT analysis and from these results it can prevent the movement of other competitors in the market world, and can take advantage of the opportunities and strengths that exist to get the desired target.
\end{abstract}

Keywords: Marketing Strategy, Market Competition. 


\begin{abstract}
Abstrak
Strategi pemasaran merupakan suatu rencana yang menyeluruh dan tertata dari setiap rancangan yang telah dibuat oleh perusahaan maupun pengusaha yang mencangkup tentang rangkaian kegiatan yang harus dijalankan untuk pemasarannya. Persaingan merupakan suatu kompetisi dari berbagai pihak pesaing lainnya dalam merebutkan suatu keunggulan dalam pasar. Persaingan juga ada dua, persaingan sehat dan tidak sehat, dalam dunia pasar suatu persaingan harus disertai usaha yang kuat untuk menghasilkan target yang diinginkan. Dari uraian diatas, rumuskan masalah penelitian ini, bagaimana strategi pemasaran yang diterapkan, strategi pemasaran dalam menghadapi persaingan pasar. Penelitian ini menggunakan pendekatan deskriptif kualitatif untuk menggambarkan meringkas berbagai kondisi. Data yang dikumpulkan dengan menggunakan metode observasi, interview(wawancara), serta dokumentasi. Tahap akhir ini menggunakan keabsahan data dengan Credibility, transferability, dependability, confirmability. Hasil penelitian ini, strategi pemasaran yang digunakan pada Toko Roti Merah Delima Kediri itu menggunakan bauran pemasaran diantaranya: Produk yang memiliki berbagai varian baik yang manis, asin, dan tawar. Harga jual dari yang Rp.3000 hingga keatas. Promosi yang digunakan itu dilakukan dengan tradisional maupun modern. Distribusi(tempat) berada di daerah yang mudah untuk dijangkau dan memiliki cabang di daerah lainnya. Dari strategi pemasaran dalam menghadapi persaingan pasar yakni menggunakan analisis SWOT dan dari hasil tersebut dapat mencegah pergerakan para pesaing lainnya dalam dunia pasar, dan dapat memanfaatkan peluang dan kekuatan yang ada untuk mendapatkan target yang diinginkan.
\end{abstract}

Kata Kunci: Strategi Pemasaran, Persaingan pasar.

\title{
Pendahuluan
}

Perkembangan perekonomian berjalan sangat pesat seiring perkembangan teknologi informasi yang semakin canggih serta tatanan perekonomian dunia yang semakin mengarah pada perdagangan bebas dan tingkat persaingan yang tinggi pada berbagai sektor industri yang ada, telah 
menyebabkan era globalisasi yang kini tidak dapat dihindari bagi setiap kalangan industri. ${ }^{1}$

Banyak usaha yang ada di Indonesia memberikan masyarakat bergelut didalam industri rumah tangga, misalnya Usaha Kecil Menengah (UKM) maupun Usaha Mikro Kecil dan Menengah (UMKM) memegang peranan yang sangat vital dalam pertumbuhan dan perkembangan perekonomian. ${ }^{2}$

Persaingan pasar sebuah industri usaha kecil dan menengah sangat bergantung pada tingkat produk yang berkembang dari kualitas produk yang ditawarkan kepada konsumen. ${ }^{3}$ Persaingan dalam dunia industri-industri merupakan hal yang tak asing lagi bagi suatu cara dalam merebut kedudukan dalam memangsakan produknya seperti industi makanan. Akan tetapi dalam dunia bisnis pastinya melakukan pemasarannya dengan cara yang halal dan jauh dari unsur kebatilan, sebagaimana sudah dijelaskan dalam Al-Qur'an surat An-Nisa' 29:

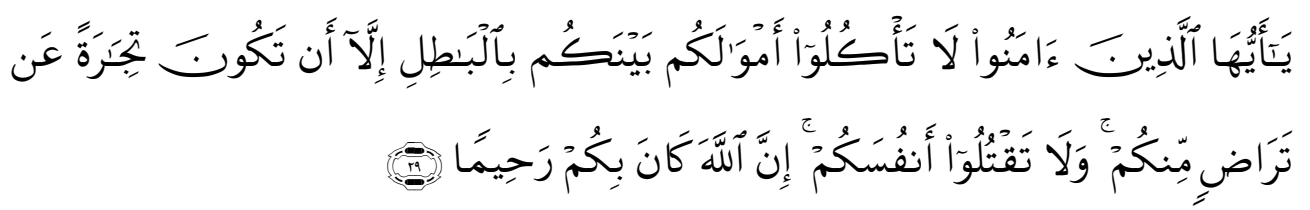

Terjemahannya: "Hai orang-orang yang beriman, janganlah kamu saling memakan harta sesamamu dengan jalan yang batil, kecuali dengan jalan perniagaan yang Berlaku dengan suka samasuka di antara kamu. dan janganlah kamu membunuh dirimu; Sesungguhnya Allah adalah Maha Penyayang kepadamu.(Q.S An-Nisa'[4]: 29). ${ }^{4}$

1 Adind fauziyyah Djayadiningrat, dkk. "Peranan Inovasi Produk Memediasi Orientasi Kewirausahaan Terhadap Kinerja pemasaran IMK Sektor Industri Makanan”, EJurnal Manajemen Unud Kota Denpasar, Vol.6 No 9, 2017:4978-5004 ISSN: 2302-8912

2 Yustina chrismardani,"Komunikasi Pemasaran Terpadu Implementasi Untuk UMKM”, Jurnal NeO-Bis, volume 8, No 2 Desember 2014, h.177.

3 Saka putra, "Analisis Industri Pangan Sub Sektor Industri Makanan Ringan Kue Bangkit dan Bolu”, JOM Fekon, vol.4, No.1 Februari 2017, h.558.

${ }^{4}$ Al-qur'an, 4: 29. 
Industri makanan merupakan suatu bentuk usaha yang cukup prospektif diIndonesia, hal tersebut dikarenakan makanan merupakan salah satu kebutuhan pokok yang harus terpenuhi. Melihat industri roti memiliki perkembangan yang semakin pesat, dalam hal ini memicu persaingan pasar yang begitu besar antara industri-industri roti satu dengan yang lainnya . Hal ini dipengaruhi oleh semakin banyaknya kompetitor. Melihat industri yang dijalankan beriringan dengan perkembangan teknologi yang semakin canggih baik media online maupun offline, sehingga para kompetitor mudah untuk meniru usaha pesaing lainnya dalam mengembangkan industri nya masingmasing. 5

Banyak dijumpai perusahaan roti berskala kecil maupun besar di seluruh Indonesia yang tetap bertahan dan mampu berkembang meskipun terkena dampak krisis ekonomi. Khususnya di Kediri memiliki banyak industri-industri roti baik yang berskala besar maupun kecil, seperti Olivia Bakery, Holand, Amanda, dan masih banyak lagi. Jika diteliti lebih jauh, toko roti seperti tadi sudah memiliki brand image di dunia online seperti GoFood, dan COD, dan memiliki cabang di luar kota Kediri. Persaingan pasar semakin meningkat antara pesaing-pesaing lainnya dalam merebut kedudukan di mata masyarakat ataupun konsumen. Dan ada salah satu toko atau industri yang ingin menyamai dengan toko roti-roti lainnya yaitu Merah Delima Kediri.

Merah Delima adalah salah satu toko roti yang berada di daerah Kota Kediri tepatnya di Jl.Penanggungan Perum GIPS A3. Sebuah industri yang memproduksi berbagai macam roti baik yang kering sampai yang roti basah. Merah delima juga mempunyai sasaran pemasaran yang sama dengan perusahaan atau industri yang lainnya yaitu masyarakat yang membutuhkan

5 Erlyha Noviyanti dan Sandi Eka Suprajang, "Strategi Pemasaran Guna Meningkatkan Volume Penjualan Dan Keputusan Pembelian Pada UD.Prima" Tulung Agung, Riset Mahasiswa Ekonomi(RITMIK), Vol.2, No.1 2015, ISSN:2407-2680, h.31. 
Khoiru Rohmah | Analisis Strategi Pemasaran...

akan produk roti tersebut, seperti kebutuhan untuk rapat, untuk pesta dan sampai penutupan ataupun pembukaan sebuah acara. Dan produk Merah Delima dipasarkannya memiliki banyak keunikan yang mungkin tidak dimiliki dari toko-toko lainnya. Diantaranya online, keliling ke desa-desa, antar ke toko-toko lainnya.

\section{Metode}

Penelitian ini menggunakan pendekatan deskriptif kualitatif untuk menggambarkan meringkas berbagai kondisi. Data yang dikumpulkan dengan menggunakan metode observasi, interview(wawancara), serta dokumentasi. Tahap akhir ini menggunakan keabsahan data dengan Credibility, transferability, dependability, confirmability.

\section{Pembahasan}

\section{Strategi yang diterapkan pada Toko Roti Merah Delima Kediri}

Strategi pemasaran merupakan suatu alat bagi perusahaan untuk mencapai tujuan perusahaan. Kemakmuran suatu perusahaan dapat dipengaruhi oleh strategi dalam jangka panjang dan perlu mempertimbangkan faktor-faktor internal maupun eksternal. ${ }^{6}$ Menjadikan strategi pokok utama dalam setiap mendirikan suatu perusahaan dan selalu mengembangkan strategi yang dimiliki.

Strategi pemasaran yang sering digunakan dalam setiap perusahaan itu dengan menerapkan bauran pemasaran (marketing mix), yang diantaranya dengan melihat produk, harga, promosi, distribusi (4p). Dalam melakukan sebuah perencanaan strategi yang akan di terapkan di pasar diperlukan suatu konsep strategi juga agar dapat memperhatikan keadaan lingkungan sekitar. 2006). h. 16

${ }^{6}$ Davit, Fred R Manajemen Strategis : Konsep. (Jakarta: Salemba Empat cet-10, 
Pemasaran memiliki suatu peranan penting dalam perencanaan strategi, maka dari itu suatu perusahaan harus benar-benar dalam memperhatikan suatu strategi dalam perusahaan yang akan dijalankan. Diantaranya bauran pemasaran yang sering digunakan suatu perusahaan adalah:

a. Produk

Produk merupakan semua yang ditawarkan ke pasar untuk diperhatikan, diperoleh dan digunakan atau dikonsumsi untuk dapat memenuhi kebutuhan dan keinginan yang berupa fisik, jasa, orang, organisasi dan ide. ${ }^{7}$ Produk juga merupakan suatu hasil dari proses yang dilakukan perusahaan, produk ini juga merupakan sesuatu yang akan diperjualkan dengan menggunakan konsep startegi melihat keadaan pasarnya.

Dalam toko roti Merah Delima Kediri menghasilkan beberapa macam produk yang diperjualkan dengan pasar dan masyarakat, dari konsumen dan masyarakat pun menerima produk yang di hasilkan dari Merah Delima pun dengan baik dan terbuka meski ada beberapa pesaing lainnya dalam memasarkan roti-roti yang sama akan tetapi toko roti Merah Delima Kediri akan tetap mempertahankan kualitas cita rasa dan akan terus menambah citra rasa yang telah dimiliki dari sebelumnya. Dari penjualan roti tersebut memiliki cakupan yang lumayan luas dari pemasaran nya sudah sampai luar kota Kediri dengan cara memesan dan akan diantar ke tempat yang dituju.

\footnotetext{
${ }^{7}$ Wenni Wahyuandari, “Analisis Matrik Boston Consulting Group (Bcg) Terhadap Portofolio Produk Guna Perencanaan Strategi Pemasaran Dalam Menghadapi Persaingan”, Jurnal Universitas Tulungagung BONOROWO, Vol. 1, No.1 (Tahun 2013), h.92.
} 


\section{Khoiru Rohmah | Analisis Strategi Pemasaran...}

b. Harga

Harga menggambarkan besarnya rupiah yang harus dikeluarkan seorang konsumen untuk memperoleh satu buah produk dan hendaknya harga akan dapat terjangkau oleh konsumen. ${ }^{8}$ Dari produk yang telah dihasilkan maka selanjutnya dalam menentukan sebuah harga untuk produk yang telah dihasilkan. Dalam menentukan harga sebaiknya melihat konsumen dan masyarakat apabila menentukan harga diatas kemampuan masyarakat dalam membeli produk tersebut akan sangat berpengaruh dalam tidak lakunya suatu produk. Dalam toko roti Merah Delima harga yang ditawarkan kepada masyarakat memiliki harga yang standar layaknya roti-roti yang lain dikarenakan melihat citra rasa roti masih seperti itu dan melihat dari masyarakat supaya mampu membeli dibandingkan roti memiliki brand-brand terkenal tetapi masyarakat tidak mampu membelinya.

c. Promosi

Menggambarkan berbagai macam cara yang ditempuh perusahaan dalam rangka menjual produk ke konsumen. ${ }^{9}$ Setelah menentukan harga yang akan diperjualkan ke masyarakat dari suatu perusahaan sebaiknya melakukan sebuah promosi agar produk yang dihasilkan perusahaan bisa terkenal dan banyak masyarakat tahu tentang produk perusahaan tersebut. Toko roti Merah Delima Kediri melakukan sebuah promosi yaitu dengan menyajikan diinternet bagi masyarakat jauh yang ingin membelinya, dan untuk masyarakat sekitar mampu langsung ketoko nya karena dengan langsung dating ketokonya akan mudah dalam memilih produk yang ingin dibeli sesuai dengan promosi yang telah ada diinternet.

\footnotetext{
${ }^{8}$ Wenni Wahyuandari, h.93.

${ }^{9}$ Wenni Wahyuandari, h.93.
} 


\section{d. Distribusi}

Tempat dimana produk tersedia dalam sejumlah saluran distribusi dan outlet yang memungkinkan konsumen dapat dengan mudah memperoleh suatu produk. ${ }^{10}$ Dan yang terakhir dari proses ini adalah tempat yang akan di distribusikan atau disaluran kepada masyrakat. Dalam sebuah perusahaan hendaknya mempunyai letak strategis dalam menjajahkan produk agar masyrakat mengetahui dari produk yang telak dibuat. Toko roti Merah Delima Kediri berada cukup mudah ditemui bagi peminat roti karena letaknya dipinggir jalan, dan toko ini memiliki cabangan agar masyarakat luas bisa menikmati atau membeli produk toko roti Merah Delima Kediri. Karena apabila tidak memilik cabang di lokasi yang berbeda masyarakat jauh pun akan kesulitan dan sulit menjakau.

\section{Strategi yang digunakan Toko Roti Merah Delima Kediri berdasarkan analisis swot dalam menghadapi persaingan pasar}

Persaingan dalam sebuah perusahaan adalah salah satu bentuk kompetisi bagi para produksi agar mendapatkan keuntungan atau peningkatan jumlah produk yang dihasilkan. Persaingan dalam dunia bisnis merupakan bentuk ancaman bagi setiap perusahaan yang ingin mengembangkan produknya. Seperti halnya toko roti Merah Delima berusaha untuk selalu mengembangkan produknya agar bisa meningkatkan dan mempertahankan kualitas yang dari awal telah di buat dan selalu melayani dengan terbaik dan ramah kepada masyarakat agar tetap berlangganan di toko roti ini, dengan cara memperbaiki setiap kelemahan internal toko roti Merah Delima Kediri dan mencoba memanfaatkan setiap peluang yang ada.

\footnotetext{
${ }^{10}$ Wenni Wahyuandari, h.93.
} 


\section{Khoiru Rohmah | Analisis Strategi Pemasaran...}

Berdasarkan hasil wawancara pemilik dan konsumen dalam faktor lingkungan internal dan eksternal pada toko roti Merah Delima Kediri sebagai berikut:

\section{A. Faktor Lingkungan Internal}

Identifikasi dari faktor internal terdapat beberapa variable meliputi Kekuatan adalah kondisi suatu perusahaan yang memberikan keunggulan untuk perusahaan dan Kelemahan adalah suatu penghambat kinerja bagi perusahaan. Berikut ini tabel faktor lingkungan internal:

a. Kekuatan

- Memiliki kualitas dan berbagai varian produk

Kualitas dalam sebuah produk merupakan hal paling penting dimana masyarakat atau konsumen sangat memperhatikan kualitas dari produk yang dihasilkan. Dalam membuat produk di toko roti ini memiliki banyak varian atau macam produk yang telah dihasilkan.

- Lokasi yang strategis

Lokasi toko roti Merh Delima Kediri sangatlah strategis karena berada di pinggir jalan raya dan tidak sulit dijangkau oleh pelanggan.

- Harga sesuai dengan kantong masing-masing konsumen

Harga sangat berpengaruh terhadap keputusan konsumen untuk membeli produk dan usaha ini memiliki produk dengan harga terjangkau.

- Memberikan yang terbaik untuk konsumen 
Kepuasan dari setiap konsumen merupakan hal yang terpenting oleh karena itu selalu memberikan yang terbaik dalam setiap produk dan yang lainnya.

- Melayani dengan semangat dan ikhlas

Dalam pelayan yang diberikan oleh toko roti Merah Delima Kediri sangatlah baik dimana para karyawan memiliki sifat ikhlas dalam menjalankan pekerjaan dan terus semangat walaupun keadaan tidak sesuai dengan kondisi hatinya.

b. Kelemahan

- Kurang lahan untuk parkir

Dimana tempat parkir diarea toko masih kurang dalam menyediakan lokasinya dan membuat konsumen yang hendak beli kebingungan dalam meletakkan kendaraan

- Masih minim dalam dunia online

Melakukan pemasaran dalam dunia online sangatlah berpengaruh dimana melihat sekarang zaman semakin maju yang mana apa-apa serba online.

\section{B. Faktor Lingkungan Eksternal}

Untuk mengidentifikasi faktor lingkungan eksternal terdapa beberapa variabel Peluang adalah suatu kondisi menguntungkan dapat memberikan manfaat untuk perusahaan dan Ancaman yaitu suatu kondisi dimana situasi tidak menguntungkan bagi perusahaan dalam lingkungannya. Selanjutnya tabel faktor lingkungan eksternal:

a. Peluang

- Diterima dimasyarakat 


\section{Khoiru Rohmah | Analisis Strategi Pemasaran...}

Hal ini merupakan suatu peluang bagi toko roti Merah Delima karena semakin masyarakat menyukai produk roti ini akan semakin besar peluang yang akan diterima oleh toko tersebut.

- Pesaing akan tertinggal dengan produk kami

Para pesaing dalam dunia insutri semakin banyak, akan tetapi dari toko roti Merah Delima Kediri akan membuat para pesaing tertinggal dengan produk yang dikeluarkan oleh toko tersebut.

- Menjalin hubungan baik terhadap pemasok

Selalu menjaga hubungan dengan para pemasok itu merupakan salah satu yang mempengaruhi pendapatan, oleh karena itu toko roti Merah Delima Kediri selalu menjaga baik dengan para pemasok.

b. Ancaman

- Semakin banyak pesaing roti lainnya

Pesaing industry di daerah Kediri sudah semakin banyak baik dari industry yang kecil sampai yang besar pun sudah mulai tumbuh dengan strategi-strategi yang mereka miliki.

- Para pesaing mempunyai strategi yang lebih hebat

Strategi setiap perusahan pasti berbeda-beda dalam menyikapi sebuah usaha, dan dari itu toko roti Merah Delima Kediri harus benar-benar mempunyai strategi yang tepat dalam menghadapi para pesaing lainnya.

Dari kondisi yang dialami toko roti Merah Delima Kediri akan menjadikan suatu tindakan atau rencana dalam menyusun dan mempertahankan suatu strategi yang akan di gunakan dalam menghadapi para pesaing industri roti lainnya. Dengan tetap menjunjung strategi dalam islam dan menjaga akidah dalam setiap berdagang atau usaha. 
Oleh karena itu peneliti juga melakukan pembobotan dan rating dalam faktor Matrix Internal Factor Analysis Summary (IFAS) dan Matrix Eksternal Factor Analysis Summary (EFAS) sebagi berikut :

a. Faktor IFAS

\begin{tabular}{|l|c|c|c|}
\hline Faktor Internal & Bobot & Rating & Bobot x rating \\
\hline $\begin{array}{l}\text { Kekuatan } \\
\text { a. Memiliki kualitas } \\
\text { dan berbagai varian } \\
\text { produk }\end{array}$ & 0,25 & 2 & 0,5 \\
b. Lokasi yang strategis \\
c. Harga sesuai dengan \\
kantong masing- \\
masing konsumen \\
d. Memberikan yang \\
terbaik untuk \\
konsumen dengan \\
e. Melayani \\
semangat dan ikhlas
\end{tabular}


Khoiru Rohmah | Analisis Strategi Pemasaran...

\begin{tabular}{|c|c|c|c|}
\hline Total & 1,0 & & 2,4 \\
\hline
\end{tabular}

Berdasarkan hasil penelitian pada analisis matriks IFAS bahwa nilai kekuatan lebih tinggi dengan jumlah 1,9 dibandingkan dengan nilai kelemahan yakni dengan jumlah 0,5 .

b. Faktor EFAS

\begin{tabular}{|c|c|c|c|}
\hline Faktor Eksternal & Bobot & Rating & Bobot $\mathrm{x}$ rating \\
\hline $\begin{array}{l}\text { Peluang } \\
\text { a. Diterima } \\
\text { dimasyarakat }\end{array}$ & 0,15 & 2 & 0,3 \\
\hline $\begin{array}{l}\text { b. Pesaing akan } \\
\text { tertinggal dengan } \\
\text { produk kami }\end{array}$ & 0,20 & 3 & 0,6 \\
\hline $\begin{array}{l}\text { c. Menjalin } \\
\text { hubungan baik } \\
\text { terhadap pemasok }\end{array}$ & 0,20 & 3 & 0,6 \\
\hline Sub total & 0,55 & & 1,5 \\
\hline $\begin{array}{lrr} & \text { Ancaman } & \\
\text { a. } & \text { Semakin } & \text { banyak } \\
& \text { pesaing } & \text { roti }\end{array}$ & 0,25 & 3 & 0,75 \\
\hline $\begin{array}{l}\text { lainnya } \\
\text { b. Para pesaing } \\
\text { mempunyai } \\
\text { strategi yang } \\
\text { lebih hebat }\end{array}$ & 0,20 & 3 & 0,6 \\
\hline Sub total & 0,45 & & 1,35 \\
\hline
\end{tabular}




\begin{tabular}{|c|c|c|c|}
\hline Total & 1,0 & & 2,85 \\
\hline
\end{tabular}

Berdasarkan hasil analisis yang dilakukan oleh peneliti pada matriks EFAS bahwa nilai tertinggi terdapat pada peluang dengan jumlah 1,5 sedangkan untuk nilai ancaman dengan jumlah 1,35.

Setelah mengetahui hasil penilaian pada tabel IFAS dan EFAS Toko Roti Merah Delima Kediri, tahap selanjutnya melakukan penjumlahan

\begin{tabular}{|c|ccc|c|}
\hline IFAS & \multicolumn{3}{|c|}{ Kekuatan (S) } & Kelemahan (W) \\
& $=1,9$ & & & $=0,5$ \\
\hline EFAS & \multicolumn{2}{|c|}{ Peluang (O) } & & Ancaman (T) $=1,35$ \\
& $=1,5$ & & & \\
\hline Total & \multicolumn{2}{|r|}{$\mathrm{S}+\mathrm{O}=3,4$} & \multicolumn{2}{|c|}{$\mathrm{W}+\mathrm{T}=1,85$} \\
\hline
\end{tabular}

matriks IFAS dan EFAS untuk menentukan keputusan strategi alternatif, berikut tabel penjumlahan

Kemudian untuk menyusun faktor-faktor sebagai alternatif usaha ini dan dapat menggambarkan dengan jelas, Maka dengan Matrik SWOT dapat mempermudah menentukan strategi yang tepat dan cara menghadapi para pesaing. Berikut alternatif strategi dengan menggunakan matrik SWOT untuk menghadapi pesaing lainnya. 
Khoiru Rohmah | Analisis Strategi Pemasaran...

\begin{tabular}{|c|c|c|}
\hline IFAS & $\begin{array}{l}\text { Kekuatan } \\
\text { a. Memiliki } \\
\text { kualitas dan } \\
\text { berbagai varian } \\
\text { produk } \\
\text { b. Lokasi yang } \\
\text { strategis } \\
\text { c. Harga sesuai } \\
\text { dengan kantong } \\
\text { masing-masing } \\
\text { konsumen } \\
\text { d. Memberikan } \\
\text { yang terbaik } \\
\text { untuk konsumen } \\
\text { e. Melayani dengan } \\
\text { semangat dan } \\
\text { ikhlas }\end{array}$ & $\begin{array}{l}\text { Kelemahan } \\
\text { a. Kurang lahan untuk } \\
\text { parkir } \\
\text { b. Masih minim } \\
\text { dalam dunia online }\end{array}$ \\
\hline $\begin{array}{l}\text { Peluang } \\
\text { a. Diterima } \\
\text { dimasyarakat } \\
\text { b. Pesaing akan } \\
\text { tertinggal } \\
\text { dengan produk } \\
\text { kami } \\
\text { c. } \text { Menjalin }\end{array}$ & \begin{tabular}{ll} 
& \multicolumn{1}{c}{ Strategi SO } \\
a. & Tetap \\
& mempertahanka \\
& n dengan baik \\
b. & Menambah dan \\
& mempertajam \\
& strategi \\
c. & Selalu
\end{tabular} & $\begin{array}{l}\text { Strategi WO } \\
\text { a. Memiki lahan } \\
\text { untuk parkir } \\
\text { b. Berusaha } \\
\text { memperhatikan } \\
\text { promosi melalui } \\
\text { media online }\end{array}$ \\
\hline
\end{tabular}




\begin{tabular}{|c|c|c|c|}
\hline & $\begin{array}{l}\text { hubungan baik } \\
\text { terhadap } \\
\text { pemasok }\end{array}$ & $\begin{array}{l}\text { berkomunikasi } \\
\text { tentang produk } \\
\text { selanjutnya }\end{array}$ & \\
\hline & Ancaman & Strategi ST & Strategi WT \\
\hline & $\begin{array}{l}\text { Semakin } \\
\text { banyak } \\
\text { pesaing roti } \\
\text { lainnya }\end{array}$ & $\begin{array}{l}\text { a. Menjaga dan } \\
\text { meningkatakan } \\
\text { produk yang } \\
\text { mutu }\end{array}$ & $\begin{array}{l}\text { a. Meningkatkan } \\
\text { strategi pemasaran } \\
\text { dalam memasarkan } \\
\text { produk }\end{array}$ \\
\hline b. & $\begin{array}{l}\text { Para pesaing } \\
\text { mempunyai } \\
\text { strategi yang } \\
\text { lebih hebat }\end{array}$ & $\begin{array}{l}\text { b. Selalu } \\
\text { mempunyai } \\
\text { cadangan untuk } \\
\text { berjaga-jaga }\end{array}$ & $\begin{array}{l}\text { b. Mempertahankan } \\
\text { setiap produk yang } \\
\text { dijualkan }\end{array}$ \\
\hline
\end{tabular}

Dilihat berdasarkan analisi swot diatas menunjukan bahawa kinerja Toko Roti Merah Delima Kediri milik bapak M. Fauzan dapat di kombinasikan antara faktor internal dan eksternal saling membutuhkan daalam menghadapi persaingan pasar yang luas dimana para pesaing-pesaing lainnya juga mempertahankan strategi-strategi yang dimiliki oleh setiap perusahaan agar mampu mendapatkan pangsa pasar yang tepat.

Toko Roti Merah Delima Kediri juga memiliki strategi yang digunakan untuk menghadapi para pesaing lainnya diantaranya dalam:

a. konsep dan perencanaan yang matang itu akan menentukan sukses atau tidaknya berbisnis, dan demi memenangkan sebuah persaingan seperti memiliki harga yang disesuaikan berdasarkan sumber bahan baku, sehingga banyak jenis yang diciptakan oleh Toko Roti Merah Delima Kediri.

b. Evaluasi dan memiliki inovasi dalam menciptakan sebuah nilai tambah dalam produk yang akan dijual. Melakukan inovasi harus dari berbagai 


\section{Khoiru Rohmah | Analisis Strategi Pemasaran...}

sisi supaya menarik pelanggan untuk melirik produk yang dijual disbanding pesaing lainnya. Selain inovasi, mengadakan evaluasi diperlukan untuk semakin memajukan usaha toko yang dilakukan secara teratur. Merah Delima juga demikian pastinya melakukan evaluasi dalam setiap produk yang dijualkan ke masyarakat, apakah produk tersebut disukai di kalangan masyarakat kelas bawah maupun atas maka dari itu diperlukan inovasi dari setiap kalangan nya agar diterima oleh masyarakat sesuai dengan uang yang dimiliki para masyarakat.

c. Memperluas jaringan pasar salah satu cara untuk memperluaskan produk yang dijualkan diantaranya bisa memperbanyak varian roti yang ditawarkan dan perluasan pangsa pasar ini juga akan menambah pendapatan dan memberi nilai tambah pada pelanggan. Toko Roti Merah Delima juga memciptakan produk yang berbeda-beda dalam disetiap cabangnya agar mengetahui masyarakat meminati produk yang mana.

d. Memiliki standarisasi dan system yang mana sangat diperlukan agar para konsumen tidak dikecewakan oleh produk dan standarisasi resep berfungsi untuk menghasilkan rasa yang seragam dalam semua cabangnya. Setelah dirasa usaha tersebut sudah mulai berjalan baiknya membuka sistem dengan membuka cabang. Toko Roti Merah Delima pun kini masih membuka 2 cabang diantaranya di pasar Pahing dan pasar Gringging.

e. Mengelola keuangan dengan baik akan menyumbangkan kesuksesan untuk menghadapi persaingan. Dalam hal ini memerlukan kepercayaan dan keyakikan juga dalam mengamanahkan personalan keuangan tersebut. 


\section{Kesimpulan}

Strategi yang biasa digunakan pada toko roti Merah Delima Kediri itu menggunakan strategi bauran pemasaran (marketing mix), diantaranya:

a. produk yaitu memiliki banyak varian rasa dan kelas tergantung rekomendasi dari konsumennya, selanjutnya

b. harga yang diberikan pun memiliki tingkatan masing-masing harga dari yang murah hingga yang mahal sesuai dengan keinginan dari konsumen.

c. promosi yang dilakukan melalui dua cara yaitu tradisional seperti berkeliling dengan sepedah, motor, hingga mobil box dan modern yang melalui internet, dan yang terakhir

d. distribusi (tempat) yang dilakukan dengan membuka cabang dibebrapa tempat untuk memudahkan masyarakat yang sekitar daerah tersebut.

Dalam hal ini Merah Delima juga membagi segmen sesuai dengan celah yang dimiliki untuk masuk kedalam hati para masyarakat.

Berdasarkan dari analisi swot dalam menghadapi persaingan pasar strategi yang digunakan pada Toko Roti Merah Delima Kediri diantaranya:

a. Konsep dan perencanaan yang matang

b. Memiliki evaluasi dan inovasi dalam setiap bisnis atau usaha ketika posisi Toko ini mengalami dititik bawah, dan inovasi dari berbagai varian roti. Mempunyai trik-trik yang tepat guna memasarkan produk roti di Toko Roti Merah Delima Kediri.

c. Memperluas jaringan pasar, diantaranya Toko Roti Merah Delima masih memiliki 2 cabang dan 1 dipusatnya di jalan Penanggungan.

d. Memiliki standarisasi yang guna untuk memberitaukan masyarakat bahwa toko roti ini sudah memiliki standarisasi resep, dan sistem yang digunakan lewat promosi lewat media tapi tidak diterjunkan ke COD maupun sejenisnya dikarenakan menghitung jarak tempuh apabila pesanan 


\section{Khoiru Rohmah | Analisis Strategi Pemasaran...}

yang diinginkan hanya sedikit, dan ada juga yang berkekiling desa istilahnya jemput bola.

e. Memiliki pengelolaan keuangan dengan baik, supaya dalam menjalankan usaha tetap bertahan minimal kalau bisa naik perlahan-lahan.

Dari analisi swot nya jua menunjukan bahwa jumlah SO lebih besar daripada WT, dari analisis ini perusahaan dapat mampu terus berkembang dengan memanfaatkan peluang dan kekuatan yang ada untuk mencapai pendapatan yang memuaskan.

\section{Daftar Pustaka}

Djayadiningrat, Adind fauziyyah, dkk. "Peranan Inovasi Produk Memediasi Orientasi Kewirausahaan Terhadap Kinerja pemasaran IMK Sektor Industri Makanan”, E-Jurnal Manajemen Unud Kota Denpasar, Vol.6 No 9, 2017:4978-5004 ISSN: 2302-8912

Chrismardani, Yustina,"Komunikasi Pemasaran Terpadu Implementasi Untuk UMKM", Jurnal NeO-Bis, volume 8, No 2 Desember 2014.

Putra,Saka, "Analisis Industri Pangan Sub Sektor Industri Makanan Ringan Kue Bangkit dan Bolu”, JOM Fekon, vol.4, No.1 Februari 2017.

Suprajang, Erlyha Noviyanti dan Sandi Eka, "Strategi Pemasaran Guna Meningkatkan Volume Penjualan Dan Keputusan Pembelian Pada UD.Prima" Tulung Agung, Riset Mahasiswa Ekonomi(RITMIK), Vol.2, No.1 2015, ISSN:2407-2680.

Davit, Fred R Manajemen Strategis : Konsep. (Jakarta: Salemba Empat cet10, 2006).

Wahyuandari, Wenni, "Analisis Matrik Boston Consulting Group (Bcg) Terhadap Portofolio Produk Guna Perencanaan Strategi Pemasaran Dalam Menghadapi Persaingan", Jurnal Universitas Tulungagung BONOROWO, Vol. 1, No.1 Tahun 2013. 